\title{
PENGEMBANGAN INSTRUMENAUTHENTIC ASSESSMENT PADA PEMBELAJARAN IPA BERBASIS KONTEKSTUAL UNTUK SISWA SMP KELAS VIII
}

\author{
Lutfiatul Lathifah $^{1}$, Sarwanto $^{2}$, Nonoh Siti Aminah ${ }^{3}$ \\ ${ }^{1}$ Program Studi Magister Pendidikan Sains FKIP Universitas Sebelas Maret \\ Surakarta, 57126, Indonesia \\ lutfiatullathifah@sch.fkip.uns.ac.id \\ ${ }^{2}$ Program Studi Magister Pendidikan Sains FKIP Universitas Sebelas Maret \\ Surakarta, 57126, Indonesia \\ sarwanto@fkip.uns.ac.id \\ ${ }^{3}$ Program Studi Magister Pendidikan Sains FKIP Universitas Sebelas Maret \\ Surakarta, 57126, Indonesia \\ nonoh_nst@yahoo.com
}

\begin{abstract}
Abstrak
Pelaksanaan penilaian pembelajaran IPA di sekolah belum dilaksanakan secara autentik dan belum te rintegrasi dengan proses pembelajaran. Penelitian ini bertujuan untuk mengembangkan instrumenn authentic assessment pada pembelajaran IPA berbasis kontekstual untuk siswa SMP kelas VIII pada materi Indera Penglihatan dan Alat Optik.Subjek dalam penelitian ini adalah siswa kelas VIII dan kelas IX SMP. Jenis penelitian ini adalah pengembangan, yang mengacu pada model pengembangan model 4-D yang dikembangkan oleh Thiagarajan, et.al terdiri dari empat tahapan yaitu: (a) tahap define (pendefinisian); (b) tahap design (perencanaan); (c) tahap develop (pengembangan); (d) tahap disseminate (penyebaran). Produk yang dihasilkan adalah instrumen authentic assessment pada pembelajaran IPA berbasis kontekstual untuk materi Indera Penglihatan dan Alat Optik kelas VIII Semester 2. Teknik analisis data yang digunakan adalah deskriptif kualitatif dan kuantitatif. Hasil penelitian menunjukkan bahwa: produk yang terdiri dari pedoman penilaian kompetensi sikap ilmiah, pengetahuan, dan keterampilan disertai lampiran perangkat pembelajaran yang terdiri dari silabus, RPP dan LKS memiliki kualitas baik dilihat dari: (1) hasil analisis data validasi, yaitu nilai rata-rata validasi isi pedoman authentic assessment pada tahap validasi sebesar 3,32 yang berarti memenuhi kriteria sangat baik; nilai rata-rata validasi isi lampiran perangkat pembelajaran sebesar 3,32 yang berarti memenuhi kriteria sangat baik; (2) hasil analisis data uji coba skala besar yang terdiri dari: (a) reliabilitas instrumen penilaian kompetensi sikap ilmiah sebesar 0,782 menunjukkan kategori tinggi; (b) reliabilitas instrumen penilaian kompetensi pengetahuan sebesar 0,54 menunjukkan kategori cukup; (c) reliabilitas instrumen penilaian kompetensi keterampilan sebesar 0,765 menunjukkan kategori tinggi; (3) hasil analisis data tahap penyebaran yang terdiri dari: (a) kevalidan dan reliabilitas tes pengetahuan menunjukkan semua item tes valid dengan reliabilitas sebesar 0,86 menunjukkan kategori tinggi; (b) respon terhadap penilaian sikap ilmiah menunjukkan kriteria yang sangat baik dengan rata-rata nilai 3,82; (c) respon terhadap penilaian keterampilan menunjukkan kriteria yang sangat baik dengan rata-rata nilai 3,73 .
\end{abstract}

Kata kunci: assessment, authentic, kontekstual, model 4-D

\section{Pendahuluan}

Peraturan Menteri Pendidikan dan Kebudayaan (Permendikbud) Republik Indonesia Nomor 53 Tahun 2015 Tentang
Penilaian Hasil Belajar oleh Pendidik pada Sekolah Menengah Pertama (SMP) mengemukakan bahwa capaian pembelajaran peserta didik meliputi aspek sikap, aspek pengetahuan, dan aspek 
keterampilan (Kemendikbud, 2015: 3). Pendidik dapat mengetahui ketuntasan belajar siswa pada kompetensi sikap ilmiah, pengetahuan, dan keterampilan dengan melakukan kegiatan penilaian. Hosnan (2014: 387) menyampaikan bahwa penilaian hasil belajar oleh pendidik dimaksudkan untuk mengukur kompetensi tertentu dalam kegiatan pembelajaran. Salah satu cara penilaian hasil belajar oleh pendidik dilaksanakan dalam bentuk Authentic Assessment (Kemendikbud, 2014: 3).

Authentic Assessment diharapkan mampu mengukur hasil belajar siswa, akan tetapi tidak sesuai dengan fakta yang ada di sekolah. Survei oleh Setiadi (2013) di 15 sekolah dasar dan menengah wilayah Indonesia bagian barat, Indonesia bagian tengah, dan Indonesia bagian timur menunjukkan bahwa guru kesulitan dalam melaksanakan penilaian di Kurikulum 2013, terutama dalam melakukan penilaian sikap, serta kesulitan dalam menganalisis instrumen penilaian dan revisi butir soal.

Hasil survei yang dilakukan oleh Ani Rusilowati (2013) terhadap 20 dari 23 guru Sekolah Menengah Pertama (SMP) 21 Semarang, menyatakan bahwa, "Sebanyak 66 persen (15 dari 23 guru) kesulitan dalam memahami model-model pembelajaran dan 79 persen (18 dari 23 guru) mengalami kesulitan membuat instrumen penilaian". Kartowagiran melakukan survei di 15 SMP se-DIY. Hasil penelitian menunjukkan bahwa kondisi guru yang melaksanakan asesmen autentik masih memerlukan perbaikan dan kualitas pelaksanaan authentic assessment di SMP yang berada di DIY belum baik. Hal ini dikarenakan sebagian besar guru merasa bahwa waktu pelatihan kurang sehingga mereka kurang paham terhadap materi yang dilatihkan, utamanya tentang materi penilaian (Kartowagiran, 2016:1).

Authentic assessment diterapkan pada siswa kelas VIII SMP Negeri 7 Surakarta. Kegiatan observasi awal dilaksanakan di SMP Negeri 7 Surakarta terhadap 32 siswa kelas VIII SMP dan guru mata pelajaran IPA. Observasi dilaksanakan selama pelaksanaan pembelajaran Ilmu Pengetahuan Alam (IPA) menunjukan bahwa penilaian pembelajaran yang diterapkan kepada siswa belum menggunakan authentic assessment. Kegiatan penilaian yang diterapkan kepada siswa masih bersifat konvensional dan belum mampu menilai seluruh kompetensi siswa mencakup kompetensi sikap ilmiah, pengetahuan, dan keterampilan.

Siswa memiliki kompetensi sikap ilmiah yang dapat diukur menggunakan authentic assessment. Berdasarkan hasil observasi, tidak ada penilaian terhadap kompetensi sikap ilmiah yang diterapkan kepada siswa. Hal ini dibuktikan dengan tidak ada lembar penilaian atau catatan yang digunakan untuk menilai sikap ilmiah siswa. Siswa yang aktif dalam proses pembelajaran dan siswa yang tidak mengikuti proses pembelajaran dengan baik tidak mendapat penilaian yang sesuai. Penilaian merupakan bagian dari pembelajaran dan bagian pokok dalam kualitas pembelajaran, sangat penting untuk meningkatkan prestasi belajar siswa yang didukung oleh pembelajaran (Ministry of Education, 2011).

Siswa memiliki kompetensi pengetahuan selama pembelajaran IPA. Bredasarkan hasil observasi, penilaian yang diterapkan kepada siswa sudah cukup baik yaitu menggunakan metode pemberian tugas, penilaian hasil catatan, dan ulangan harian. Selain penilaian harian, siswa juga mendapatkan penilaian sumatif di tengah semester dan akhir semester. Penilaian yang dilaksanakan belum mampu menilai seluruh aspek kompetensi pengetahuan siswa diantaranya kemampuan mengetahui, memahami, menerapkan, menganalisis, dan mengevaluasi pengetahuan faktual, konseptual, prosedural, dan metakognitif. Proses pembelajaran IPA mengembangkan kompetensi 
keterampilan siswa. Berdasarkan hasil observasi, siswa tidak difasilitasi untuk mengembangkan keterampilan konkrit dan keterampilan abstrak. Kegiatan pembelajaran yang tidak mendukung pengembangan keterampilan siswa berdampak pada tidak ada authentic assessment yang diterapkan kepada siswa pada kompetensi keterampilan. Frances Edwards, (2012) mengemukakan bahwa metode terbaik dari penilaian pembelajaran akan memberikan siswa kesempatan untuk mengembangkan keterampilannya seperti menyelidiki sesuatu di laboratorium atau di lapangan merupakan hal yang sangat bermakna.

Jun-Ming SU (2011) menjelaskan bahwa authentic assessment dapat diterapkan jika didukung oleh pembelajaran yang sesuai. Kemendikbud (2014: 3) dalam Permendikbud No 103 tentang Pembelajaran pada Pendidikan Dasar dan Pendidikan Menengah menjelaskan bahwa authentic assessment dapat diterapkan pada pembelajaran yang dilaksanakan berbasis aktivitas dengan salah satu karakteristiknya yaitu kontekstual. Hasil observasi dalam proses pembelajaran IPA di SMP, siswa mengikuti pembelajaran IPA menggunakan pendekatan kontekstual. Pada permulaaan kegiatan belajar, siswa diberi pertanyaan untuk mengingat kembali materi sebelumnya. Selama proses pembelajaran, siswa mengaitkan materi pembelajaran dengan kegiatan dalam kegiatan sehari-hari. Pelaksanaan pembelajaran dengan pendekatan kontekstual diprediksi dapat mengembangkan kompetensi siswa pada ranah sikap, pengetahuan, dan keterampilan.

Menurut Oka (2011: 82), pembelajaran kontekstual (Contextual Teaching and Learning) merupakan proses pembelajaran yang berlangsung alamiah dalam bentuk kegiatan bekerja dan mengalami, bukan transfer pengetahuan dari guru ke siswa sehingga strategi pembelajaran lebih dipentingkan daripada hasil.Berdasarkan permasalahan yang telah dipaparkan, diperlukan authentic assessment yang sesuai standar untuk diterapkan kepada siswa sehingga dapat mengukur seluruh kompetensi siswa dan diterapkan pada pembelajaran yang sesuai dengan karakteristik IPA. Berdasarkan permasalhan tersebut, diperlukan pengembangan instrumen authentic assessment pada pembelajaran IPA berbasis kontekstual untuk siswa kelas VIII SMP. Tujuan dilakukan pengembangan instrumen authentic assessment pada pembelajaran IPA berbasis kontekstual adalah untuk : (1) mendeskripsikan proses penyusunan instrumen authentic assessment pada pembelajaran IPA berbasis kontekstual untuk siswa di SMP; (2) mendeskripsikan kelayakan instrumen authentic assessment pada pembelajaran IPA berbasis kontekstual untuk siswa di SMP.

\section{Metode Penelitian}

Penelitian ini merupakan salah satu bentuk penelitian dan pengembangan atau yang dikenal dengan istilah Research and Development (R\&D). Penelitian dan pengembangan ini mengacu pada model 4-D (Four-D Model) yang dikembangkan oleh S. Thiagarajan, et. al. (Thiagarajan, et.at. (1974). Model 4-D merupakan model penelitian dan pengembangan yang memiliki empat tahapan yaitu define (pendefinisian), design (perencanaan), develop (pengembangan), dan disseminate (penyebaran). Pembagian tahapan juga terbagi hampir merata, sehingga waktu yang dibutuhkan untuk melaksanakan penelitian dan pengembangan dengan model 4-D tidak terlalu lama.

Pengembangan instrumen authentic assessment pada pembelajaran IPA berbasis kontekstual dilakukan di Surakarta. Subyek penelitian ini adalah 5 guru IPA dan 300 siswa. Pada tahap pendefinisian dilaksanakan analisis kebutuhan dengan angket dan wawancara, 
serta analisis dokumen penilaian yang dimiliki oleh guru IPA. Pada tahap perancangan dilakukan dengan studi literatur dan validasi oleh pembimbing. Pengembangan instrumen authentic assessment pada tahap develope (pengembangan) dilakukan validasi, uji coba skala kecil dan uji coba skala besar. Validator pada tahap validasi terdiri dari dua orang ahli, dua orang reviewer, dan dua orang peer reviewer. Penyusunan angket validasi menggunakan skala Likert, yaitu menggunakan rentang mulai dari angka 1 sampai dengan 4 (Sukardi, 2008: 147). Pada tahap uji coba skala kecil, subyek penelitian yaitu sejumlah 38 siswa dan pada tahap uji coba skala besar sebanyak 64 siswa. Pengembangan instrumen authentic assessment pada tahap disseminate (penyebaran) dilakukan di 5 sekolah se Kota Surakarta dengan masing-masing sekolah sebanyak 2 kelas dengan total 300 siswa dan 5 guru IPA.

Analisis data yang digunakan yaitu analisis kualitatif dan kuantitatif. Analisis data kualitatif dilaksanakan dengan menggunakan teknik triangulasi data dengan model analisis data menurut Miles \& Huberman (1992: 20). Analisis data kuantitatif dilakukan menggunakan teori tes modern dengan bantuan program Quest dan program SPSS 16.0. Analisis data kuantitatif dilakukan untuk mendapatkan validitas dan reliabilitas instrumen.

\section{Hasil Penelitian dan Pembahasan}

Penelitian dan pengembangan instrumen authentic assessment pada pembelajaran IPA berbasis kontekstual untuk materi Indera Penglihatan dan Alat Optik kelas VIII Semester 2. Model 4-D yang dikembangkan oleh Thiagarajan, et.al digunakan dalam proses pengembangan instrumen dalam penelitian ini. Terdapat empat tahapan yang dilakukan dalam pengembangan instrumen authentic assessment yaitu: (a) tahap define (pendefinisian); (b) tahap design (perencanaan); (c) tahap develop (pengembangan); (d) tahap disseminate (penyebaran). Masing-masing tahapan model 4-D yang digunakan, terangkum dalam penjabaran sebagai berikut.

Tahap pendefinisian dilakukan analisis pelaksanaan pembelajaran dan analisis pelaksanaan penilaian pembelajaran, analisis peserta didik, analisis konsep, analisis tugas, dan analisis tujuan pembelajaran. Hal ini sesuai dengan pengembangan model 4-D oleh Thiagarajan, et.al yang menyatakan bahwa terdapat lima langkah dalam tahap pendefinisian diantaranya analisis awal akhir, analisis peserta didik, analisis konsep, analisis tugas, dan analisis tujuan pembelajaran (Thiagarajan,et. al., 1974:6). Analisis pelaksanan pembelajaran dan analisis pelaksanaan penilaian pembelajaran dilakukan dengan teknik angket dan wawancara.

Tahap perencanaan merupakan tahap yang dilalui setelah melakukan tahap pendefinisian yang bertujuan untuk merancang bentuk dasar produk pembelajaran. Pada tahap perencanaan, pelaksanaan authentic assessment terintegrasi dengan pembelajaran kontekstual. Hal ini dikarenakan authentic assessment merupakan penilaian proses dan penilaian hasil sekaligus. Menurut Nurgiyantoro (2013: 13), penilaian proses adalah penilaian yang dilakukan sepanjang dan bersamaan dengan proses pembelajaran melalui berbagai macam teknik dan instrumen.

Tahap develop (pengembangan) merupakan tahap lanjutan setelah tahap design (perancangan). Pada tahap pengembangan dilakukan pengembangan pada instrumen asesmen kompetensi sikap ilmiah, pengetahuan, dan keterampilan. Penilaian kompetensi sikap ilmiah mengacu pada KD 2.2. Menunjukkan perilaku ilmiah (memiliki rasa ingin tahu, objektif, jujur, teliti, tekun, cermat, bertanggung jawab, 
INKUIRI: Jurnal Pendidikan IPA

Vol. 8, No. 1, 2019 (hal 40-47)

https://jurnal.uns.ac.id/inkuiri

terbuka, kritis, kreatif, inovatif dan peduli lingkungan) dalam aktivitas sehari-hari. Penilaian pengetahuan diterapkan pada lima komponen pembelajaran kontekstual. Lima komponen yang dilakukan penilaian pengetahuan diantaranya pemodelan (modelling), bertanya (questioning), inkuiri (inquiry), konstruktivisme (constructivism), dan masyarakat belajar (learning community). Penilaian pengetahuan berupa tes tertulis pilihan ganda. Menurut (Sukardi, 2009: 119) soal pilihan dapat membangun obyektifitas yang lebih baik dan dapat mengevaluasi dengan cakupan materi yang lebih luas. Penilaian kompetensi keterampilan diterapkan pada tiga komponen pembelajaran kontekstual. Tiga komponen yang dilakukan penilaian kompetensi keterampilan diantaranya pemodelan (modelling), inkuiri (inquiry), dan masyarakat belajar (learning community). Instrumen authentic assessment pada pembelajaran kontekstual dilengkapi dengan lampiran. Bagian isi lampiranterdiri dari perangkat pembelajaran: silabus, Rencana Pelaksanaan Pembelajaran (RPP), dan Lembar Kerja Siswa (LKS).

Tahap pengembangan terdiri dari tiga rangkaian kegiatan yaitu validasi, uji coba skala kecil dan uji coba skala besar. Pada tahap validasi, dilakukan validasi terhadap produk berupa instrument authentic assessment dan perangkat pembelajaran (silabus, RPP, dan LKS) oleh dua ahli, dua reviewer, dan dua peerreviewer. Hasil validasi terhadap draf produk authentic assessment ditunjukkan pada tabel 1 berikut.

Tabel 1. Hasil Validasi Isi Draf Authentic assessment pada Pembelajaran IPA Berbasis Kontekstual
P-ISSN: $2252-7893$

E-ISSN: 2615-7489

DOI: 10.20961/inkuiri.v8i1.31812

\begin{tabular}{|c|c|c|c|c|c|c|c|}
\hline \multirow{3}{*}{ Jenis Draf } & \multicolumn{6}{|c|}{ Validator } & \multirow{3}{*}{$\begin{array}{l}\text { Total } \\
\text { rata- } \\
\text { rata }\end{array}$} \\
\hline & \multicolumn{2}{|c|}{ Ahli } & \multicolumn{2}{|c|}{ Reviewer } & \multicolumn{2}{|c|}{$\begin{array}{c}\text { Peer } \\
\text { Reviewer }\end{array}$} & \\
\hline & I & II & I & II & I & II & \\
\hline \multirow{5}{*}{$\begin{array}{l}\text { Desain } \\
\text { Authentic } \\
\text { assessment } \\
\text { Draf } \\
\text { Penilaian } \\
\text { Sikap } \\
\text { Ilmiah } \\
\text { Draf } \\
\text { Penilaian } \\
\text { Pengetahu } \\
\text { an } \\
\text { Draf } \\
\text { Penilaian } \\
\text { Keterampi } \\
\text { lan }\end{array}$} & 3,00 & 3,12 & 3,18 & 2,88 & 3,65 & 2,91 & 3,12 \\
\hline & 4,00 & $\mathbf{3 , 4 2}$ & 3,42 & 2,75 & $\mathbf{3 , 3 3}$ & 3,17 & $\mathbf{3 , 3 5}$ \\
\hline & 3,38 & 3,24 & 3,68 & 3,05 & 3,91 & 3,35 & 3,44 \\
\hline & 4,00 & 3,24 & 3,53 & 3,05 & $\mathbf{3 , 3 3}$ & 3,00 & 3,36 \\
\hline & \multicolumn{6}{|c|}{ Nilai rata-rata draf I } & 3,32 \\
\hline
\end{tabular}

Hasil validasi terhadap perangkat pembelajaran (silabus, RPP, dan LKS) ditunjukkan pada tabel 2 berikut.

Tabel 2. Hasil Validasi Perangkat Silabus, RPP,

\begin{tabular}{|c|c|c|c|c|c|c|c|}
\hline \multirow{3}{*}{$\begin{array}{c}\text { Jenis } \\
\text { Perangk } \\
\text { at }\end{array}$} & \multicolumn{6}{|c|}{ Validator } & \multirow{3}{*}{$\begin{array}{l}\text { Total } \\
\text { rata- } \\
\text { rata }\end{array}$} \\
\hline & \multicolumn{2}{|c|}{ Ahli } & \multicolumn{2}{|c|}{ Reviewer } & \multicolumn{2}{|c|}{$\begin{array}{c}\text { Peer } \\
\text { Reviewer }\end{array}$} & \\
\hline & I & II & I & II & I & II & \\
\hline Silabus & $\mathbf{3 , 4 3}$ & 3,71 & 3,71 & 3,00 & 3,86 & 3,00 & 3,45 \\
\hline RPP & 3,17 & 3,50 & 3,77 & 3,10 & 3,72 & 3,11 & 3,40 \\
\hline LKS & $\mathbf{3 , 0 0}$ & 3,27 & 3,91 & 3,09 & $\mathbf{3 , 5 5}$ & 3,09 & 3,32 \\
\hline
\end{tabular}

Berdasarkan hasil penilaian dari validator, draf instrumen authentic assessment pada pembelajaran IPA berbasis kontekstual mendapatkan nilai rata-rata 3,32 yang berarti memiliki kriteria sangat baik (Saiffudin, 2005). Hasil validasi terhadap perangkat yang terdiri dari silabus, RPP, dan LKS dengan nilai rata-rata 3,32 memiliki kriteria sangat baik (Saiffudin, 2005).

Tahap uji coba skala kecil dilakukan kepada 32 siswa. Uji coba skala kecil dilakukan untuk instrumen penilaian kompetensi sikap ilmiah, kompetensi pengetahuan, dan kompetensi keterampilan. Pada tahap uji coba skala kecil, dilakukan uji coba tes kompetensi pengetahuan materi Indera Penglihatan dan Alat Optik serta angket respon siswa terhadap pernyataan pada penilaian kompetensi sikap ilmiah dan penilaian 
kompetensi keterampilan. Menurut Azwar (2012: 7) reliabilitas merupakan penerjemahan dari kata reliability. Suatu pengukuran yang mampu menghasilkan data yang memiliki tingkat reliabilitas tinggi disebut reliable. Hasil reliabilitas produk instrumen penilaian pengetahuan berupa tes pilihan ganda adalah 0,03 yang berarti sangat rendah menurut Suharsimi (1995:71). Sebanyak 9 soal tes diterima dan sebanyak 21 soal tes direvisi.

Uji coba skala besar dilakukan kepada 64 siswa. Berdasarkan hasil analisis uji coba skala besar, reliabilitas instrumen penilaian kompetensi sikap sebesar 0,782 menunjukkan kategori tinggi menurut Suharsimi (1995:71). Reliabilitas instrumen penilaian kompetensi pengetahuan sebesar 0,54 menunjukkan kategori cukup menurut Suharsimi (1995:71). Reliabilitas instrumen penilaian kompetensi keterampilan sebesar 0,765 menunjukkan kategori tinggi menurut Suharsimi (1995:71).

Tahap penyebaran merupakan tahap yang dilalui setelah melakukan tahap pengembangan dalam penelitian (Thiagarajan,et. al., 1974:9). Tahap penyebaran dilakukan dengan 300 siswa dan 5 guru IPA sebagai responden di 5 SMP. Berdasarkan hasil penilaian dari seluruh responden, produk pengembangan memiliki kriteria sangat baik. Hasil analisis item tes menunjukkan seluruh item tes valid dan reliabel dengan reliabilitas sebesar 0,86 menunjukkan kategori tinggi menurut Suharsimi (1995:71). Pada penilaian kompetensi sikap ilmiah menunjukkan kriteria yang sangat baik (Saiffudin, 2005) dengan nilai rata-rata respon 3,82. Pada penilaian kompetensi keterampilan menunjukkan kriteria yang sangat baik dengan nilai ratarata respon 3,73 (Saiffudin, 2005). Hal ini menunjukkan bahwa produk pengembangan instrumen authentic assessment pada pembelajaran IPA berbasis kontekstual untuk siswa SMP layak untuk digunakan.
Proses pengembangan produk instrumen authentic assessment pada pembelajaran IPA berbasis kontekstual untuk siswa SMP menggunakan model 4D yang dikembangkan oleh Thiagarajan, et.al terdiri dari empat tahapan yaitu: (a) tahap define (pendefinisian): melakukan analisis kebutuhan di sekolah; (b) tahap design (perencanaan): membuat rancangan pedoman authentic assessment kompetensi sikap ilmiah, pengetahuan, dan keterampilan; (c) tahap develop (pengembangan): melakukan validasi dan uji coba produk instrument authentic assessment; (d) tahap disseminate (penyebaran): melakukan penhyebaran produk. Produk berupa instrumen authentic assessment pada pembelajaran IPA berbasis kontekstual untuk siswa SMP terdiri dari pedoman authentic assessment kompetensi sikap ilmiah, pengetahuan, dan keterampilan disertai lampiran perangkat pembelajaran yang terdiri dari silabus, RPP dan LKS untuk materi Indera Penglihatan dan Alat Optik kelas VIII Semester 2.

Instrumen authentic assessment pada pembelajaran IPA berbasis kontekstual yang dikembangkan dalam penelitian ini terdiri dari pedoman penilaian kompetensi sikap ilmiah, pengetahuan, dan keterampilan disertai lampiran perangkat pembelajaran yang terdiri dari silabus, RPP dan LKS. Kualitas instrumen yang dikembangkan dilihat dari: (a) hasil analisis data validasi, antara lain: (i) nilai rata-rata validasi isi pedoman penilaian autentik pada tahap validasi, yaitu sebesar 3,32 yang berarti memenuhi kriteria sangat baik (Saiffudin, 2005); (ii) nilai rata-rata validasi isi lampiran perangkat pembelajaran pada tahap validasi, yaitu sebesar 3,32 yang berarti memenuhi kriteria sangat baik (Saiffudin, 2005) (b); hasil analisis uji coba skala kecil yang terdiri dari kevalidan dan reliabilitas tes pengetahuan dengan hasil reliabilitas tes sebesar 0,03 yang berarti sangat rendah menurut Suharsimi (1995:71) (c) hasil analisis data 
uji coba skala besar yang terdiri dari: (1) reliabilitas instrumen penilaian kompetensi sikap sebesar 0,782 menunjukkan kategori tinggi menurut Suharsimi (1995:71); (2) reliabilitas instrumen penilaian kompetensi pengetahuan sebesar 0,54 menunjukkan kategori cukup menurut Suharsimi (1995:71); (3) reliabilitas instrumen penilaian kompetensi keterampilan sebesar 0,765 menunjukkan kategori tinggi menurut Suharsimi (1995:71); dan (d) hasil analisis data tahap penyebaran yang terdiri dari: (i) kevalidan dan reliabilitas tes pengetahuan menunjukkan semua item tes valid dengan reliabilitas sebesar 0,86 menunjukkan kategori tinggi menurut Suharsimi (1995:71); (ii) respon terhadap penilaian sikap ilmiah menunjukkan kriteria yang sangat baik dengan rata-rata nilai 3,82 (Saiffudin, 2005); (iii) respon terhadap penilaian keterampilan menunjukkan kriteria yang sangat baik dengan rata-rata nilai 3,73 (Saiffudin, 2005). Berdasarkan keseluruhan hasil tersebut, menunjukkan bahwa instrumen authentic assessment pada pembelajaran IPA berbasis kontekstual memiliki kualitas yang baik. Pengembangan instrumen authentic assessment pada pembelajaran IPA berbasis kontekstual ini memiliki beberapa keterbatasan, diantaranya : (1) instrumen penilaian kompetensi sikap ilmiah dan kompetensi keterampilan tidak diterapkan kepada siswa pada tahap uji coba skala kecil, tetapi hanya dilakukan untuk mendapatkan angket respon siswa; (2) pengembangan instrumen authentic assessment pada pembelajaran IPA berbasis kontekstual tidak disebarkan kepada 300 siswa di 10 sekolah tetapi disebarkan kepada 300 siswa di 5 sekolah; (3) penelitian dilaksanakan di kelas IX semester I pada tahap uji coba skala kecil dan disseminasi, seharusnya dilaksanakan di kelas VIII semester II.

\section{Kesimpulan dan Rekomendasi}

Berdasarkan tujuan penelitian, hasil dan pembahasan maka dapat disimpulkan bahwa: proses pengembangan produk instrumen authentic assessment pada pembelajaran IPA berbasis kontekstual untuk siswa SMP kelas VIII menggunakan model 4-D yang dikembangkan oleh Thiagarajan, et.al terdiri dari empat tahapan yaitu: (1) tahap define (pendefinisian); (2) tahap design (perencanaan); (3) tahap develop (pengembangan); (4) tahap disseminate (penyebaran). Instrumen authentic assessment pada pembelajaran IPA berbasis kontekstual layak untuk digunakan dilihat dari hasil analisis data validasi, hasil analisis data uji coba skala besar, dan hasil analisis data tahap penyebaran. Berdasarkan hasil dan pembahasan maka rekomendasi dalam penelitian ini adalah pihak pendidik IPA dan peserta didik hendaknya dapat berperan aktif dalam melaksanakan authentic assessment pada pembelajaran IPA berbasis kontekstual. Peneliti lain yang ingin melakukan penelitian sejenis hendaknya dapat melakukan penelitian lanjutan untuk mengukur efektifitas instrument authentic assessment sehingga dapat mewujudkan penilaian yang berkualitas.

\section{Daftar Pustaka}

Azwar, Saifuddin. (2012). Reliabilitas dan Validitas Edisi IV. Yogyakarta: Pustaka Pelajar

Edwards, Frances (2012). Quality assessment by science teachers: Five focus areas (Versi Elektronik). Journal of Science Education International 24 (2).Diakses pada tanggal 19 April 2015 .

Hosnan, M. (2014). Pendekatan Saintifik dan Kontekstual dalam Pembelajaran Abad 21. Bogor: Ghalia Indonesia. 
Jun-Ming SU, dkk. (2011).OPASS: An Online Portfolio Assessment and Diagnosis Scheme To Support Web-Based Inquiry Experiment (Versi Elektronik). The Turkish Journal online Of Educational Technologi, 10 (2). Diakses pada tanggal 19 April 2015

Kartowagiran, Badrun. (2016). Model Asesmen Autentik untuk Menilai Hasil Belajar Siswa Sekolah Menengah Pertama (Smp): Implementasi Asesmen Autentik di Smp (Versi Elektronik). Jurnal Penelitian dan Evaluasi Pendidikan, 20 (2). Diakses pada tanggal 3 Januari 2017 dari http://journal.uny.ac.id/index.php/jp ep/article/view/10063/8450

Kementerian Pendidikan dan Kebudayaan Republik Indonesia. (2014). Permendikbud No 104 Tahun 2014 Tentang Standar Penilaian Pembelejaran. Jakarta: Kementerian Pendidikan dan Kebudayaan

Kementerian Pendidikan dan Kebudayaan Republik Indonesia. (2015). Permendikbud No 53 Tahun 2015 Tentang Penilaian Hail Belajar oleh Pendidik pada Sekolah Menengah Pertama (SMP). Jakarta: Kementerian Pendidikan dan Kebudayaan

Kementerian Pendidikan dan Kebudayaan Republik Indonesia. (2016). Permendikbud No 23 Tahun 2016 Tentang Standar Penilaian Pembelejaran. Jakarta: Kementerian Pendidikan dan Kebudayaan

Miles \& Huberman. (1992). Data Kualitatif. Terj. Ahmad Ali Riyadi. Jakarta : UI Press. (Buku asli diterbitkan 1984)

Ministry of Education. (2011). Assessment: Schooling sector. Ministry of Education.

Nurgiyantoro, Burhan. (2013). Penilaian Pembelajaran Bahasa Berbasis Kompetensi Edisi Pertama. Yogyakarta: BPFE

Oka, Anak Agung. (2011). Peningkatan Kualitas Pembelajaran IPA Di SMP
Melalui Pembelajaran Kontekstual (Versi Elektronik) .Bioedukasi, 2 (1), 1-11. Diakses 18 April 2015, dari http://www.ummetro.ac.id/jurnalprodi-2-bioedukasi-(jurnal-pend$\underline{\text { biologi) }}$

Rusilowati, Ani. (2013, 16 Desember). Masih Banyak Guru Kesulitan Implementasi Kurikulum Baru. Okezone. Diperoleh 21 Januari 2016, dari http://www.okezone.com

Saifuddin. (2005). Metode Penelitian. Yogya: Pustaka Pelajar

Setiadi, Hari. (2016). Pelaksanaan Penilaian pada Kurikulum 2013 (Versi Elektronik). Jurnal Penelitian dan Evaluasi Pendidikan, 20 (2). Diakses pada tanggal 3 Januari 2017 dari http://journal.uny.ac.id/index.php/jp ep/article/view/7173/8446

Suharsimi. (1995). Prosedur Penelitian. Jakarta: Rineka Cipta

Sukardi, (2008), Metodologi Penelitian Pendidikan, Jakarta: Bumi Aksara.

Sukardi. (2009). Evaluasi Pendidikan, Prinsip \& Operasionalnya. Yogyakarta: Bumi Aksara

Thiagarajan, et.at. (1974). Instructional Development CNI For Training Teachers Of Exceptional Children CD O A sourcebook. Indiana: Indiana University Bloomington 